\title{
TWO NEW SPECIES OF GNAMPTOGENYS, AND AN ACCOUNT OF MILLIPEDE PREDATION BY ONE OF THEM
}

\author{
BY WiLLIAM L. BROWN, JR. \\ Department of Entomology \\ Cornell University \\ Ithaca, New York 14853
}

\section{INTRODUCTION}

In dealing with these two very interesting new neotropical Gnamptogenys, I have extended a revisionary effort made earlier (Brown, 1960C), and have consulted a newer, comprehensive review of the genus in manuscript sent me in 1991 by John Lattke (Lattke, 1993) and written after he had looked at these two species during a stay in Ithaca. I began the descriptions more than a decade ago, but suspended the work in favor of other pressing obligations. I am pleased now to offer them, along with observations on the hunting behavior of one of the new species, as a tribute to my mentor and friend, Prof. Frank M. Carpenter, with my gratitude and best wishes for his ninetieth birthday.

\section{Gnamptogenys lineolata new species (Figs. 1, 2)}

Diagnosis, worker: A medium-small species (head width about 1.2, WL near $1.6 \mathrm{~mm}$ ) with sides of head subparallel and feebly convex; eyes gently convex, EL almost one-fifth HL, situated distinctly behind mid-HL; vertexal margin weakly concave. Mandibles triangular, basal margin oblique, meeting the apical margin at an obtuse angle with a tooth, one of a short series of spaced, uneven, low teeth on the apical margin; blades striate to near apex. Apron of free clypeal margin straight, with rounded lateral corners; a narrow triangular space is left between the margin and the basal mandibular margins at full closure. Antennal scapes surpassing vertexal margin by about their apical thickness in fullface view; scapes smooth and shining, with spaced punctulae.

Manuscript received 5 October 1992 

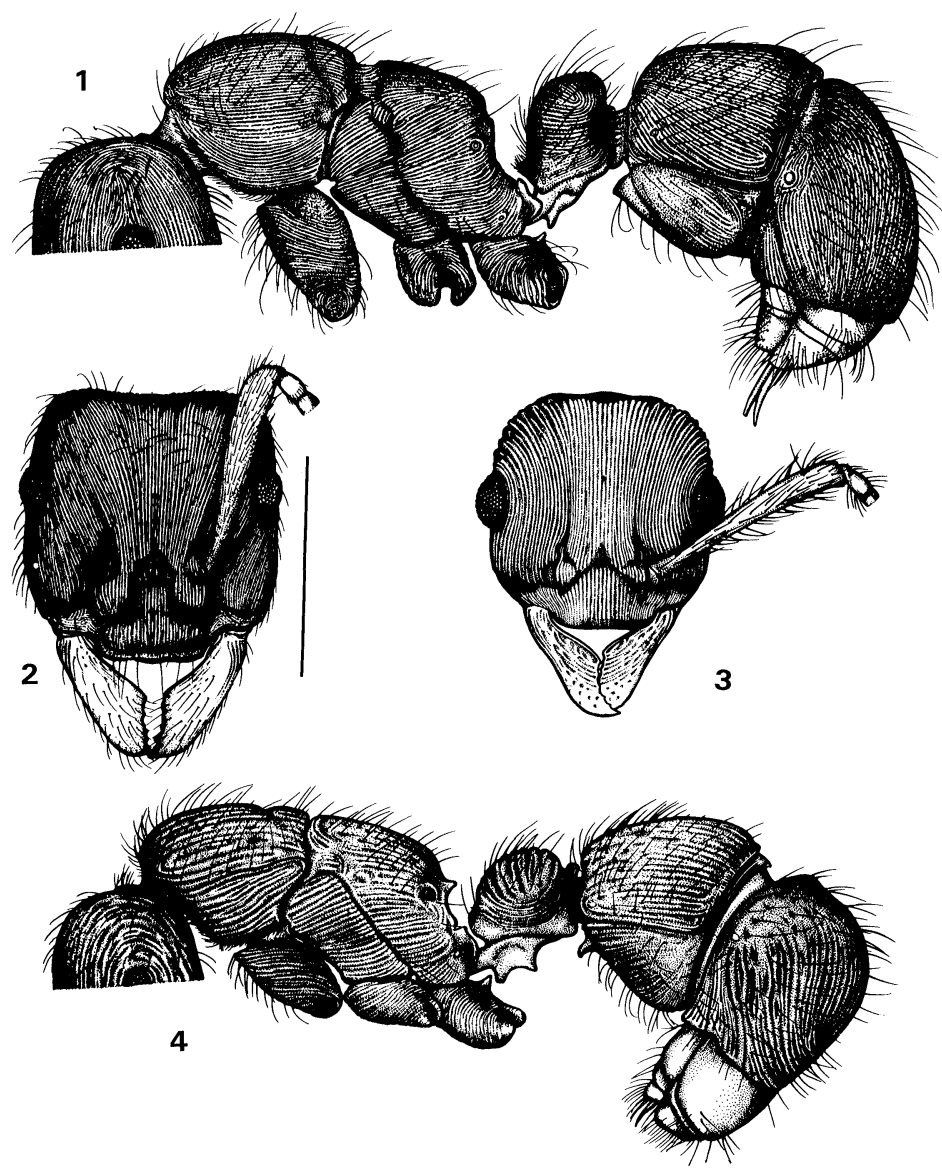

Figs. 1-4. Figs. 1, 2. Gnamptogenys lineolata new species, worker paratype, side view of body and dorsal (full-face) view of head. Figs. 3, 4. G. ingeborgae new species, worker paratype ex type nest, dorsal (full-face) view of head and side view of body. Scale line equals $1.0 \mathrm{~mm}$. Drawings by Amy Trabka and the author.

Promesonotal suture arcuate, impressed, but not breaking the integumental surface; metanotal groove broad, impressed, so that the side-view dorsal outline of the alitrunk is gently convex at the promesonotum, and slightly lower and more feebly convex over the propodeal dorsum; declivity of propodeum rounding into 
dorsum, with a low, obtuse suggestion of a propodeal tooth barely perceptible on each side above mid-height; propodeal spiracle slightly raised, its round opening directed caudolaterad, placed very near the declivity near mid-height. Petiole thick but raised, node back-tilted, apex strongly rounded and highest caudad, broader than long; subpetiolar process triangular, with acute apex directed forward.

Prora trailing a prominent carina caudad; constriction between A3 and A4 distinct, but moderate; T4 arched, so that S4 is moderately reduced, and the apical segments of the gaster are directed ventrad and slightly anteriad. Sculpture moderately shining, consisting mostly of very fine, regular, longitudinal striation over dorsal surfaces of head, alitrunk and gaster, arched over petiolar node, about 30-33 costulae between frontal carinae. Color brownish black to yellowish brown, the lighter examples often infuscate dorsad; appendages brown to yellowish.

Holotype worker: TL 5.6, HL 1.20, HW 1.14 (CI 94), ML 0.52 (MI 43), SL 1.00 (SI 88), EL 0.22, WL 1.70, metafemur L 1.20, metatibia L $1.00 \mathrm{~mm}$. Worker paratypes $(\mathrm{n}=9)$ : TL 5.2-5.8, HL 1.19-1.30, HW 1.11-1.19 (CI 90-96) mm.

Worker, further description: Although the sides of the head are approximately parallel in full-face view, the anterior part is actually very slightly wider at about halfway between the eye and the anterior corner of the head; vertexal outline, while weakly concave mesad, is filled in by the convex outline of the nuchal rim behind it. The frontal lobes are moderately expanded, but do not cover all of the antennal insertions. The comb of stiff hairs in the basitarsal concavity opposing the strigil of the fore leg lacks a longer, specialized, stiff seta present in some other Gnamptogenys species.

Queen, male and lava unknown.

Type locality: REPUBLICA DOMINICANA, Prov. La Vega: (Parque Nacional) La Cienaga, $1100 \mathrm{~m}$., broad-leaf valley forest with some pine, 7 workers: 2 workers under large stone in soil, plus 5 workers taken from berlesates of leaf litter at the same general locality of 4 February 1975 and 17 July 1986 (sort made 19 July), 


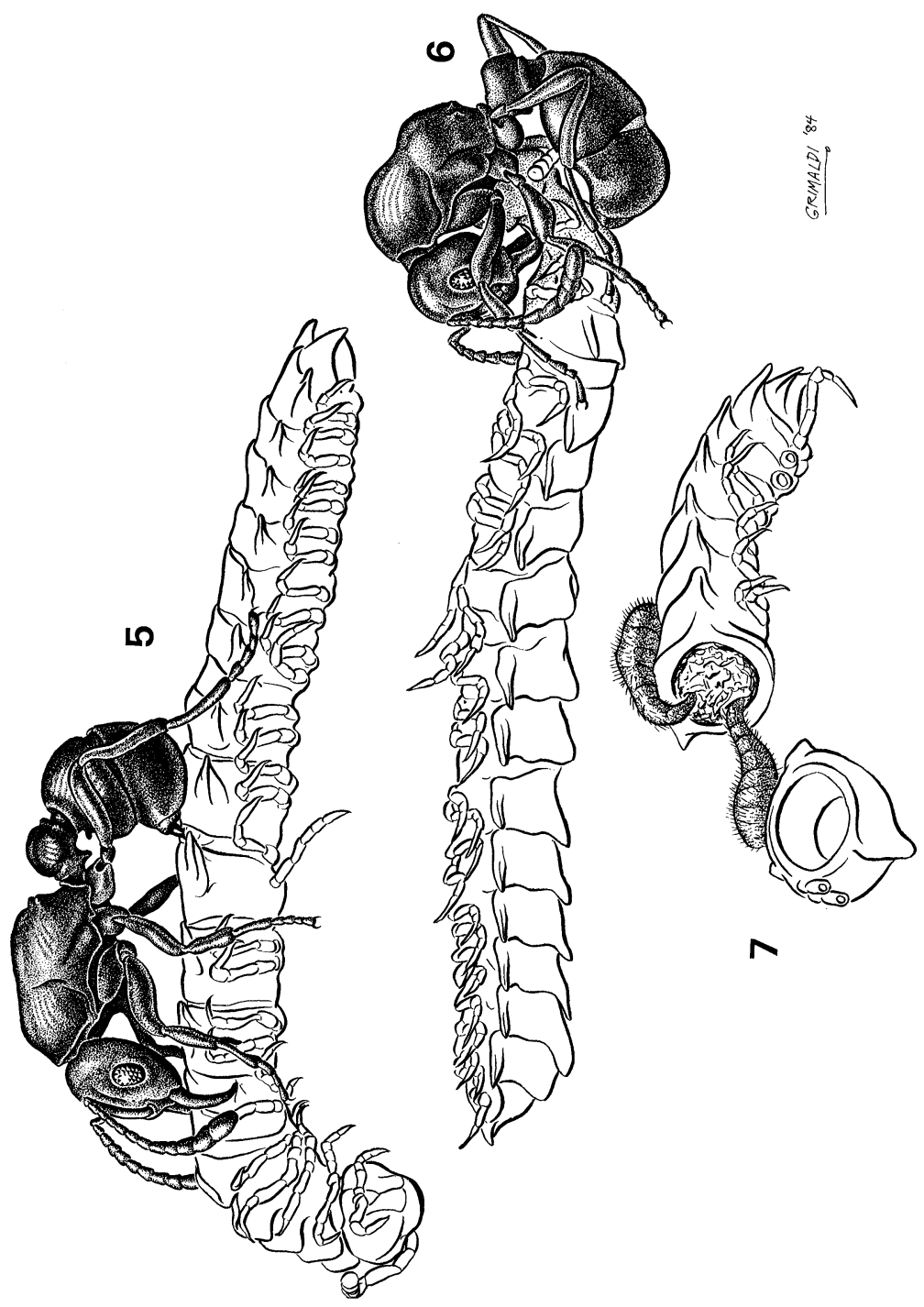


leg. W. L. Brown. Prov. La Vega, El Rio to Bonao, Km 22 (in or near Casabito Forest), 2 foraging workers from roadside quebrada at about $1000 \mathrm{~m}$ in degraded forest remnant, 7 and 16 February 1975, leg. W. L. and D. E. Brown. Holotype in MCZ-Cambridge, paratypes in MCZ, CUIC-Ithaca, BMNH-London. Coll. J. Lattke, Caracas.

This interesting species from central Hispaniola differs from the five previously described (endemic) Gnamptogenys from the island, two of them fossil in amber, by its combination of triangular mandibles, fairly large eyes, size, form of petiole, and fine, regular, costulate sculpture. G. lineolata seems to be a rather primitive species among both the Hispaniolan and the overall New World congeners. In Lattke (1993), G. lineolata would apparently fall into his rastrata group, and in his key it runs to couplet 54, where it agrees with rastrata in that the scape surpasses the vertexal margin by its apical width, but differs from rastrata in its larger size, finer sculpture, dentate mandibles, and quadrate head shape, among other things.

\section{Gnamptogenys ingeborgae new species (Figs. 3-7)}

Diagnosis, worker: A small species (HW about 0.75 to $0.9 \mathrm{~mm}$ ) with head nearly as broad as long, sides convex; eyes large, convex, protruding, placed slightly behind mid-HL; mandibles narrowly triangular, their basal margin oblique but meeting the apical margin at a distinct, obtuse, rounded or dentate basal angle, their concave apical (masticatory) margins with 4-9 small, irregular, spaced teeth or denticles; dorsal surfaces of blades costulate to apical third. Clypeus with the median lobe or apron weakly convex on its anterior margin and rounded at its lateral corners; a narrow triangular space is left between it and the basal mandibular margins

Figs. 5-7, Hunting and processing of millipede Oxidus gracilis by Gnamptogenys ingeborgae new species. Fig. 5, Stinging position of the ant on the millipede, with the millipede already dead or paralyzed. Fig. 6, Ant begins to bite at ventral postcephalic area of outstretched millipede while pressing its undercurled gastric apex against the millipede's postcephalic dorsum in preparation for wrenching off its head region; action takes place in or just outside ant's nest cell. Fig. 7, Feeding of small ant larvae on millipede carcass on floor of nest cell. Drawings by David Grimaldi. 
at full closure. Antennal scapes surpassing vertexal margin in fullface view by a little less than twice their apical width, their surfaces smooth and shining with scattered punctulae. Alitrunk robust and only moderately tapered caudad, its dorsal outline gently biconvex in side view; promesonotal suture present as a shallowly impressed line that does not break the integumental surface; metanotal groove strong but narrow. Propodeal spiracle slightly elevated, with a round opening that is directed caudad as well as laterad, situated very near the propodeal tooth, which is small and subrectangular of the declivity a little above mid-height; declivity rounding into sides and dorsum of propodeum. Petiolar node low and bun-shaped, about as broad as long in dorsal view, widest caudad; boldly transversely costate; subpetiolar process with an acute, oblique tooth front and rear. Postpetiole separated from A4 by a very deep and broad constriction; T4 robust and strongly arched $90^{\circ}$ or more, so that $\mathrm{S} 4$ is correspondingly reduced, and the apical segments of the gaster point ventroanteriad. Integument shining but longitudinally costulate over head, pronotum, and sides of alitrunk and gaster; dorsum of posterior alitrunk and gaster variably costate to prevailingly smooth and shining, with coarse scattered punctures. Color reddish brown, appendages lighter.

Worker, holotype: TL 4.8, HL 0.96, HW 0.90 (CI 94), ML 0.42 (MI 44), SL 0.88 (SI 97), EL 0.22, WL $1.52 \mathrm{~mm}$. Worker paratypes, from type nest series $(\mathrm{n}=8)$ : TL 4.4-4.9, HL 0.92-0.97, HW 0.86-0.90 (CI 91-94), WL 1.49-1.54 mm.

Worker, further description: Head with broadly rounded posterior corners and weakly convex sides; vertexal outline, while weakly concave mesad, is filled in by the convex outline of the nuchal rim behind it. First segment of antennal funiculus longer than the second; first through third longer than broad; fourth through tenth about as broad as long, apical antennomere about twice as long as broad. Costulae of cephalic sculpture strong and regular but slightly wavy in a few places, with scattered coarse piligerous punctures intervening, about 20-23 costulae between the frontal carinae. Legs mostly smooth and shining. The row of stiff hairs in the basitarsal concavity opposing the strigil of the fore leg lacks a longer, specialized, stiff seta. Erect and suberect, fine, fairly abun- 
dant pilosity on most body surfaces, including underside of head (fig. 3).

Queen, dealate, paratypes from type nest $(\mathrm{n}=2)$ : TL 5.7-5.8, HL 0.98, HW 0.91-0.92 (CI 93-94), ML 0.38 (MI 39), SL 0.89 (SI 97-98), EL 0.24, WL 2.28-2.30 mm. One queen eclosed and lost her wings about a month after the original collection.

Strays from Villavicencio, worker $(n=4)$ : TL 4.1-4.8, HL 0.85-0.89, HW 0.78-0.80 (CI 90-93), WL 1.32-1.38 mm. Queen, dealate $(n=2)$ : HL 0.84 , HW $0.76 \mathrm{~mm}$.

A queen and 2 workers from Putumayo differ from the type nest series and the Villavicencio strays in sculpture: costate/striate surfaces of the propodeal and gastral dorsum, especially T3, are largely replaced by smooth and shining ones with some coarse scattered punctures; a band of short, longitudinal costulae remains on the caudal fifth of T3. The Putumayo specimens are also at the small end of the body size range: worker TL $4.1, \mathrm{HL} 0.84$, HW 0.76 (CI 90), WL 1.25-1.26 mm. Queen, dealate: TL 4.7, HL 0.90, HW 0.84, (CI 93), WL $1.56 \mathrm{~mm}$.

Male ( $\mathrm{n}=1$ of 9 ex type nest): TL 4.0 , HL 0.72 , HW including eyes 0.58, ML 0.24), SL 0.18, EL 0.31, WL 1.44, forewing L $3.6 \mathrm{~mm}$., Mandibles with nearly straight masticatory margins with small but distinct, separated teeth in series. Median dorsal part of head around antennal insertions and ocelli with some fine, indefinite rugulation, but remainder of body prevailingly rather smooth and fairly shining. Notauli distinct and deep, forming a complete Y. Petiole low and somewhat flattened; prora forming a distinct lip. Color piceous black, with dark brown legs and wing veins; antennae yellowish brown; however, other males reared in the type nest are dull yellow or brownish yellow, and probably teneral.

Type nest from COLOMBIA, Depto. Cundinamarca: beside Bogotá-Villavicencio Highway near Km 79 (near border of Depto. Meta), steep slope of the Rio Negro ravine at about $1100 \mathrm{~m}$ elevation; in a small piece of rotten wood on the floor of shady mesic rain forest, leg. I. Zenner-Polania and W. L. Brown, 1 July 1976. 
Additional collections, COLOMBIA: Depto. Meta, Villavicencio, 1-4 March 1972, S. and J. Peck, rain forest leaf litter berlesate B233., workers and dealate queens. Depto. Putumayo, Villa Garzón, 17 July 1977, leg. D. Jackson, dealate queen and 2 workers, part of a series in BMNH-London.

In Lattke (1993) G. ingeborgae fits into the rastrata group, and runs in his key to couplet 54 , where it finds an uneasy berth because of the intermediate distance by which the scapes surpass the vertexal margin in full-face view, but if one turns from the rather delicate scape character to body size, then ingeborgae runs to the small rastrata, from which it differs in having: the masticatory margin of the mandibles denticulate, with at least several separated denticles (rather than edentate in rastrata), the promesonotal suture, though variable in development, clearly detectable over half or more of the alitrunk dorsum (rather than absent in rastrata), and the longitudinal costulae often weakly defined, obsolescent, or even absent on the propodeal dorsum and first gastric tergite (rather than costulae always strongly defined and contiguous in rastrata).

\section{Hunting and Prey Handling by G. ingeborgae}

At the time of collection, the G. ingeborgae nest contained about 15 workers, one queen, larvae, a few pupae in cocoons, and a tiny midden of the whitish, separated empty body rings of two or more small, possibly immature millipedes, thought to belong to suborder Spirobolida. This colony was returned alive to the U. S. with some loss of workers and brood, and a few adult workers, a queen and males emerged during July-December 1976.

The colony was kept in a small plaster-of-Paris nest with glass top and chamber diameter of $9 \mathrm{~cm}$. The ants constructed a rude nest cell at one wall of this; the cell cavity occupied about $1 \mathrm{~cm}^{2}$, and consisted of tiny fragments of rotten wood and other debris, open to view above.

The first prospective prey, introduced to the chamber opposite the nest cell, was a local (Ithaca, New York) julid millipede found beneath a stone in my garden. It was probably of genus Orojulus, common in this area. The millipede, ca. $1.5 \mathrm{~cm}$ long, uncoiled and began to move around the perimeter of the chamber, where it soon 
encountered a foraging ant worker. The reaction was immediate and energetic. The ant attacked the millipede, grasping it with its mandibles in the anterior quarter of the body while facing in the same direction as the millipede, astride its dorsal aspect, and with the tip of its gaster applied to the victim's integument, apparently at an intersegmental articulation. The millipede responded by coiling and uncoiling violently for a few seconds while it apparently was being stung, but within 20 seconds it was stretched out and was still, with an occasional twitch for a few seconds. The behavior of the ant appeared to be frantic, and soon gave way to obvious aversion and signs of acute distress, dismounting, rapid cleaning strokes of the forelegs over head and antennae, and body dragging on the chamber floor-actions that I had learned from watching other Ponerinae, including Gnamptogenys spp., are attempts to get rid of noxious substances produced by the arthropods attacked.

During this aversive episode, which lasted for a minute or so, the ant stood apart from the dead or paralyzed millipede and showed no interest in it, eventually leaving it alone after further bouts of self-cleaning with the legs. Similar results followed introductions of julids to the chamber on several later occasions, including some that were made after offerings of alternative millipede taxa, including Oxidus in particular. The one exception to this behavior occurred when a julid, circling the perimeter of the chamber, chanced to breach the ants' nest cell wall. On this occasion the response of the ants was immediate and obviously one of distressed defense, with some workers moving brood, while two attacked the millipede. After one of the ants stung the millipede to immobility, its body was removed after a lapse of a few minutes by a single worker that dragged the carcass to the opposite side of the observation chamber in several stages, punctuated with grooming motions of its own body.

The impression left by the observations of julid contacts was that the ants responded defensively, and also aversively, in a relatively frenetic, generalized way. By contrast, behavior during trials with another millipede were more deliberate and stereotyped.

This millipede was Oxidus (=Fontinaria) gracilis, according to T. Eisner after William T. Keeton. This species was moderately abundant during the summer and fall of 1976 in wood-bark chip mulch put around shrubbery on parts of the Cornell University campus at Ithaca. It is a pinkish-brown polydesmid, averaging 
about $1.2 \mathrm{~cm}$ long in this population. About 20 trials were made with introductions of Oxidus into the chamber containing the $G$. ingeborgae (denoted $\mathrm{G})$ nest.

When the Oxidus $(\mathrm{O})$ made its circumambulation of the chamber, it soon met a foraging $\mathrm{G}$ worker coming in the opposite direction. On contact, $\mathrm{O}$ reversed its walk, while $\mathrm{G}$ showed an obvious alertness and followed the millipede closely. Its approach was not the frenzied attack it and other $\mathrm{G}$ workers had made on the julids, but instead was a relatively methodical overtaking of $\mathrm{O}$, followed by a climb onto its back on the anterior half of the millipede's body, which it grasped with its mandibles. With its antennae playing about the dorsum of $\mathrm{O}$ near O's head, $\mathrm{G}$ moved back slightly and applied its gastral tip to the region of an intersegmental articulation on the dorsum of $\mathrm{O}$, where it apparently inserted its sting, judging from the sudden violent reaction of $\mathrm{O}$, which coiled and uncoiled two or three times rapidly for 20-25 sec, and then lay still in the stretched-out position (Fig. 5). G continued in the stinging position for a few seconds longer, and then dismounted and stood beside $\mathrm{O}$ as it groomed its own antennae, head and body with its forelegs.

Much to my surprise and annoyance, $\mathrm{G}$ briefly frisked its antennae over $\mathrm{O}$, and then left $\mathrm{O}$ lying on the chamber floor, stretched out dorsal side up and motionless. $G$ wandered a bit, ending by returning to its own nest cell, taking about 9 min to arrive there. After approximately the same period of time in the nest, grooming and remaining still, the same $G$ worker left the nest cell and returned by a fairly direct route over the distance of 5-6 $\mathrm{cm}$ to the the millipede. After two episodes of dragging the carcass a short way toward the nest cell, with some brief excursions and grooming sessions a short distance away from $\mathrm{O}$, the ant left $\mathrm{O}$ lying venter up. After about 10-15 min of this seemingly dilatory behavior, $\mathrm{G}$ went to $\mathrm{O}$ head first and reached over the upraised mandibles of the immobile millipede to seize it with her own jaws by the "throat," that is, the ventral region of O just caudad of O's mouthparts, somewhat as in Fig. 6, but without the under-curling of the ant's gastral apex. With a heave from this position, the ant threw the body of the millipede over her own body and, facing the same way while maintaining her grip in the millipede's postgnathal region, moved off to the nest with the carcass over her back and trailing to the floor behind. This maneuver recalled for me the 
figure in W. M. Mann's National Geographic Magazine article (Mann, 1934: Pl. VI) on ants, of Gnamptogenys (=Emeryella) schmitti carrying a millipede in Haiti, and scenes I myself had witnessed with other millipede-hunting ants of the same genus (unpublished notes).

Once arrived in the nest cell, $\mathrm{G}$ threw her burden down off her back by a forward heave, so that the carcass was again stretched out, ventral side up, with the ant still clutching its throat. The ant commenced working in this postgnathal area of $\mathrm{O}$, her mandibles biting into an intersegmental area, and in a short time-a matter of seconds-she broke off the head-and-gnathal region of the millipede by pulling backwards. At that time, I was surprised and puzzled at the apparent ease with which this decapitation was accomplished, and it was only after repeated observations of Gnamptogenys ingeborgae operating with Oxidus prey that I saw how this was done, always in the same way. Once my attention was drawn to the whole action, and not just the biting, I saw that the ant's gaster was curled under the head of the millipede, with the tip applied to a postcephalic tergum of $\mathrm{O}$ (fig. 6). In this way, the gastral apex of the ant served as a fulcrum against which the mandibular tug could break off the head and associated segments of the millipede in a neat and efficient way. Once the cephalic complex of the millipede was removed, the ant dragged the carcass to the vicinity of some half-grown larvae lying on the floor of the cell nearby. In the presence of the prey, the larvae showed some movement of the head and the "neck" area of their thoracic segments, and they were soon placed on the prey at the truncated end of its body, where they began to feed as they stretched out their long, neck-like forebodies to reach inside the open ring. They remained thus, continuously feeding, and at times the huntress and other adult nestmates joined in the feast, side by side with the larvae. As the larval heads reached deeper into the prey, the first body ring of $\mathrm{O}$ came loose as it was freed of its muscles and other tissues; it was removed and laid aside by a worker (fig. 7). The feeding progressed on into the carcass in the same way, with the rings being removed one at a time until the contents of the body of the millipede had in a few hours been consumed. At the same time some larvae were put on the cephalic part of the millipede, which was eaten out in the same way. 
As other duties allowed during the autumn of 1975, I made further introductions of Oxidus, and a few of julids, into the observation chamber. It did appear that times for some stages of prey handling were shorter when $\mathrm{O}$ had been withheld for a longer period - that is, when the colony was hungry. But the constancy of certain behaviors by $\mathrm{G}$ workers was remarkable.

$\mathrm{G}$ always attacked $\mathrm{O}$ in the same relatively methodical way. Almost always, the prey was stung and then thrown down in the way already described. Delay in delivery of the prey to the nest cell was also a constant feature, although the delay varied from ten minutes or so, up to more than an hour. It is possible that this delay may be adaptive in allowing the partial or complete dissipation of defensive allomones that $\mathrm{O}$ secreted. The removal of the prey's head was another highly stereotyped act, as was the manner of presenting the prey to the larvae, and their feeding.

The experimental approach to exploring some of the stimuli involved in this interesting sequence unfortunately was delayed until so late in the autumn that the supply of Oxidus had dwindled to practically nothing, and even julids were hard to collect, so only one trial could be performed. The result, though, was highly suggestive. I already knew from Thomas Eisner (1978 and personal communication) that Oxidus had a defensive pheromone complex consisting of HCN, benzaldehyde, and phenol; while julids secrete quinone. So I took a living julid, roughed it up for a little while with a toothpick, and gently wiped it with tissue paper, after which I dipped it briefly in tepid distilled water, and then dried it with tissue paper. This was done to remove its defensive secretion as completely as possible. I then took a live Oxidus in watchmaker's forceps and rubbed, one side and then the other, on the julid, with the object of transferring the $\mathrm{O}$ secretion to the julid. The julid was put into the observation chamber, where it soon uncoiled and began the usual circling walk around the perimeter. It did not appear to behave abnormally after its treatment and bath.

The surprise came when it met its nemesis, a G worker that met it head on from the opposite direction-apparently a chance contact. G immediately climbed aboard the julid, faced in the same direction, and sought to sting. The behavior was the same methodical procedure that $\mathrm{G}$ workers had used with Oxidus, and not the frantic response they had usually shown with julids. After the 
usual thrashing about, coiling and uncoiling, the julid soon was still and stretched out, venter up, but not quite in the same position assumed by $\mathrm{O}$ in death (or paralysis), for the head of the julid was raised somewhat more above the floor. G soon left the julid and wandered for a few minutes, then came back, seized the julid by the postgnathal area and started to try to heave the millipede over her back for transport. But the julid is shaped differently from a polydesmid, is more rigid in death, and is smoother and presumably more slippery, so the ant had difficulty trying to carry her booty in the usual manner, and finally mostly dragged the carcass on its side toward the nest. The delays and excursions usual for $\mathrm{G}$ with Oxidus prey were also made with the julid. But the colony had been deprived of prey for a couple of days, and after less than a half hour, the ant reached and entered the nest cell with her julid. She soon got it onto its back, but not without some difficulty, and began to try to remove the head complex in the usual way, grasping the postgnathal area while doubling her gastric tip under and against the julid's postcephalic dorsal region. Here she ran into real difficulty, because she did not seem to be able to apply the gastric apex as an efficient fulcrum, because the julid seemed more convex, more slippery, or harder in this area. At any rate, after trying repeatedly for a couple of minutes, $\mathrm{G}$ ceased trying, entered into a bout of self-grooming, and soon left the julid lying on its side on the nest floor. After about ten minutes, another ant worker came, and after various delays, dragged the julid from the nest cell, across the chamber, and abandoned it there, where it remained unmolested for two days until the chamber was cleaned.

Two hours after the julid was removed from the nest cell by the ant, I introduced the lone Oxidus to the observation chamber. This was the specimen used to lend its secretion to the julid of the trial just described. In a short while, this Oxidus was attacked and processed in the manner usual for that species, and observations made after a lapse of two hours found the prey in the nest cell, separated into the usual two pieces, with larvae feeding on them in the normal way.

The episode reported was not repeated and it is of course mainly of interest in framing questions for further investigation. But an hypothesis is in order to explain it: the defensive allomones of the polydesmid Oxidus and other diplopod taxa having the same 
chemical complex (Eisner et al. 1978) serve as kairomones for their specialized predators (in this case, Gnamptogenys of certain species-groups that feed upon them).

It is reasonable, I think, to speculate more broadly and to consider how often may the generally-acting defensive allomones of animals be the very kairomones of the specialized predators of those same animals. This phenomenon is already well known in plants and their enemies, which include animals of course (reviewed by Gershenzon and Croteau, 1991). Why may it not also be true of animals and animals?

\section{SUMMARY}

Abstract: Gnamptogenys lineolata from Republica Dominicana and $G$ ingeborgae from Cis-Andean Colombia are described as new. The latter species was found on one occasion associated with the body rings of a small millipede, and observations of this ant in a laboratory artificial nest in the U. S. showed that it would hunt, kill, and provision its nest with a local polydesmid defended by a hydrogen cyanide-benzaldehyde-phenol allomone combination, but rejected julid quinone-defended millipedes. The contrasting behavior of G. ingeborgae with these two prey taxa is described, and a crude substitution experiment suggests that the cyanide system, perhaps acting through it biochemical concomitants, serves as the major kairomone directing this ant's hunting behavior.

\section{ACKNOWLEDGEMENTS}

I thank Amy Trabka (Figs. 1-4) and David Grimaldi (Figs. 5-7) for their skillful illustrations, and Thomas and Maria Eisner, Michael McDonald, and Pierre R. Fraissinet for help with preparation of the manuscript.

\section{Literature Cited}

BRown, W. L.

1958 Contributions toward a reclassification of the Formicidae. II. Tribe Ectatommini (Hymenoptera). Bulletin of the Museum of Comparative Zoology, Harvard University, 118: 171-362.

Eisner, T., Alsop, D., Hicks, K., Meinwald, J.

1978. Defensive secretions of millipedes. Chapter 3 in Bettini, S., editor, Arthropod Venoms, Handbuch der experimentallen Pharmakologie, (new series) 48: 41-72; Berlin: Springer Verlag. 
Gershenzon, J., Croteau, R.

1991. Terpenoids. Pp. 165-219 in Rosenthal and Berenbaum, (Editors), Herbivores: their interactions with secondary plant metabolites. Vol. 1: The chemical participants. Edition 2. New York, Academic Press.

LATTKE, J. E.

1993. Revision of the ant genus Gnamptogenys Roger in the New World (Hymenoptera: Formicidae). Journal of Hymenoptera Research (submitted).

MANN, W. M.

1934. Stalking ants, savage and civilized. National Geographic Magazine, 66: 171-192. 

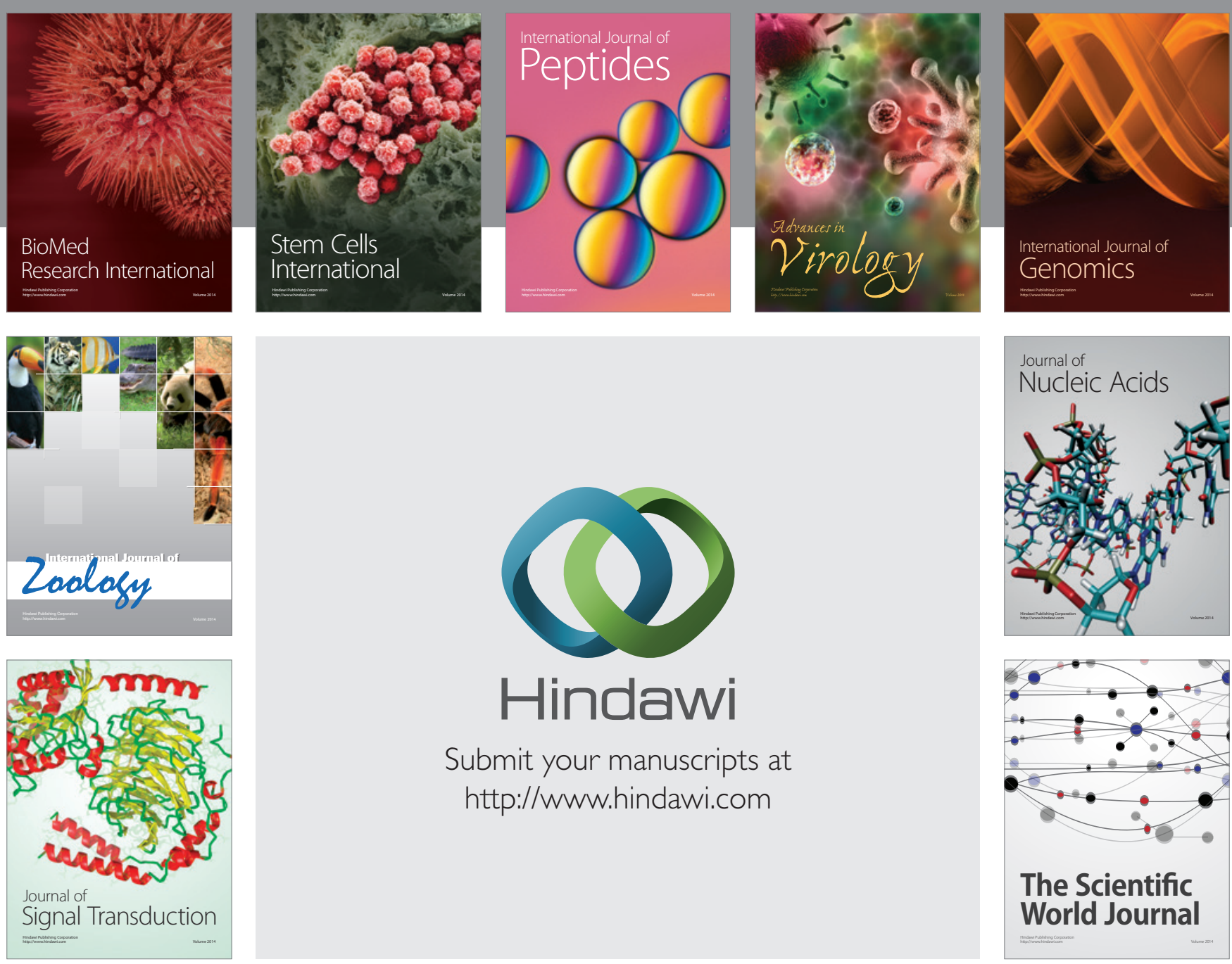

Submit your manuscripts at

http://www.hindawi.com
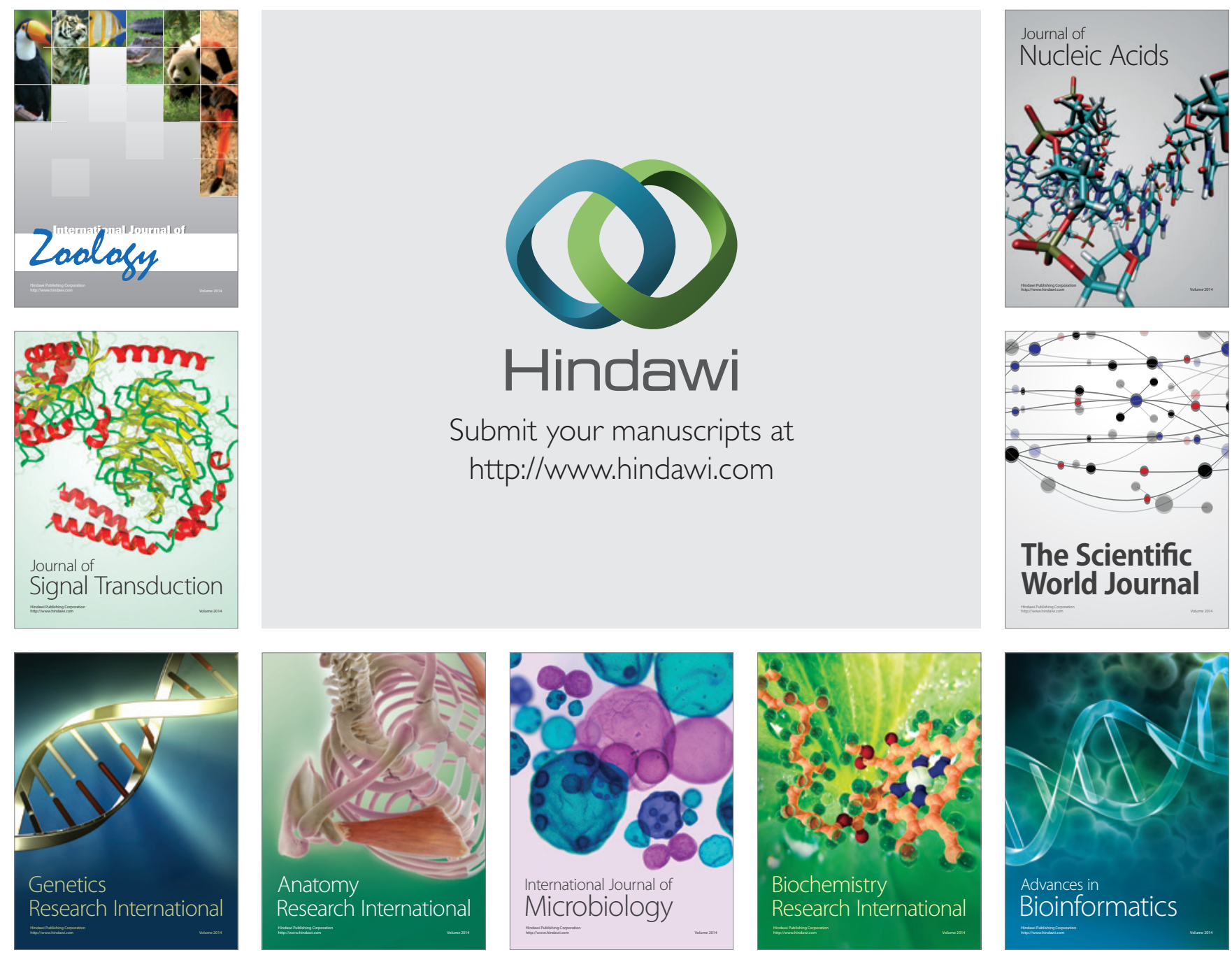

The Scientific World Journal
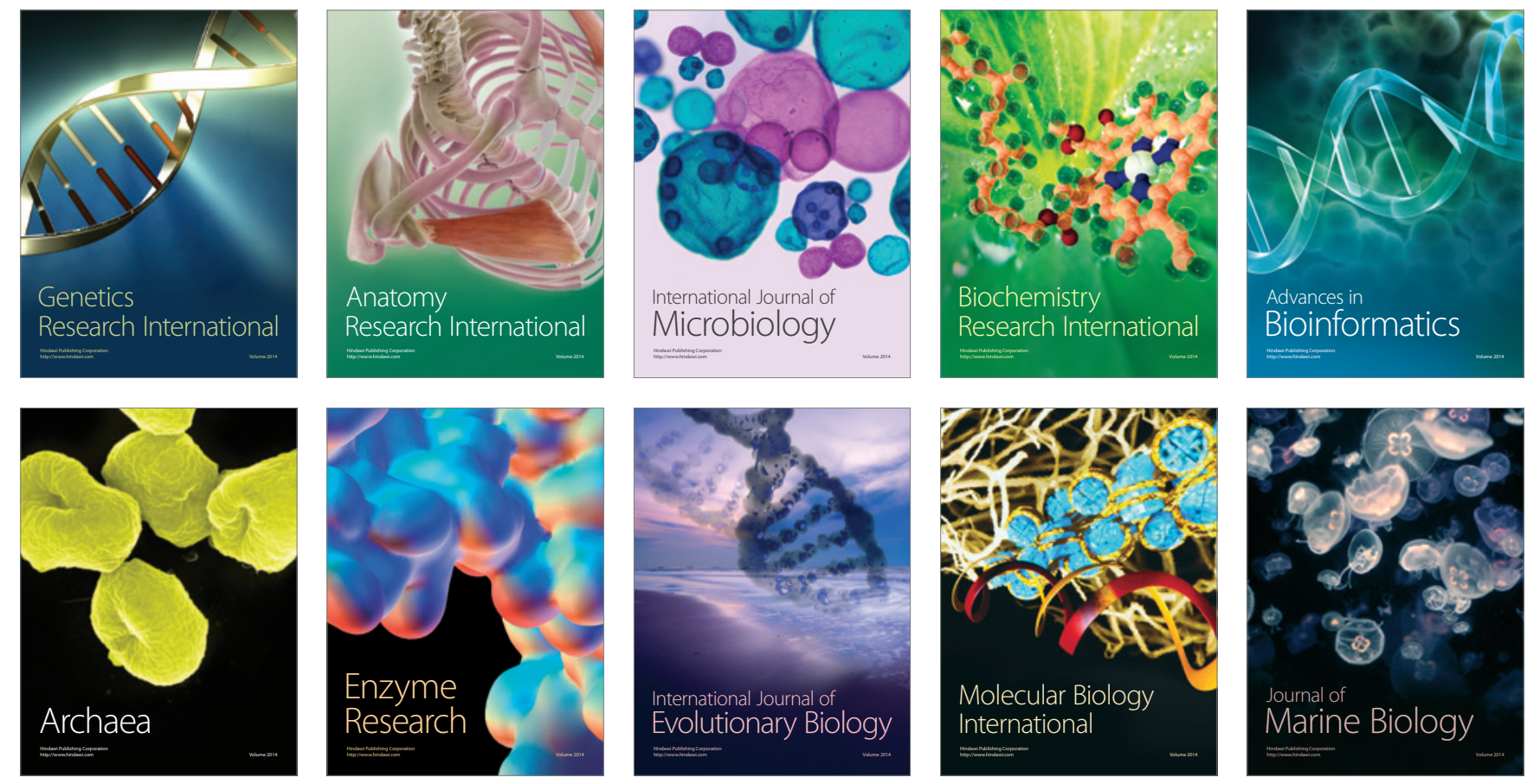